\title{
Mikä vernakulaari?
}

\author{
Outi Fingerroos, Niina Hämäläinen ja Ulla Savolainen
}

$\mathrm{T}$ ämän teemanumeron aihe on vernakulaarin käsite. Numeron neljässä artikkelissa vernakulaaria lähestytään käsitehistoriallisesta ja tapaustutkimusten näkökulmasta. Artikkeleissa tarkastellaan ensinnäkin sitä, minkälaisia merkityksiä vernakulaarin käsitteellä on ollut eri aikoina. Toiseksi niissä eritellään, minkälainen asema vernakulaarin käsitteellä sekä sille annetuilla merkityksillä on ollut eri tieteenaloilla ja niiden tutkimuskohteiden määrittelyssä. Kolmanneksi teemanumeron artikkeleissa analysoidaan useita tapaustutkimuksia vernakulaarin käsitteen ja sen tarjoamien näkökulmien kautta samalla käsitettä pohtien. Teemanumeron tavoitteena on tuoda monipuolisesti esiin, miten vernakulaarin käsitettä on tutkimuksessa käytetty, ja mikä sen anti on perinteen- ja kulttuurien tutkimukselle.

Tässä johdannossa esittelemme teemanumeron koostavien artikkeleiden lisäksi vernakulaarin käsitteen taustoja. Käymme läpi myös vernakulaarin käyttöä erityisesti folkloristiikan näkökulmasta, käsitteeseen kytkeytyviä ongelmia ja sen analyyttistä potentiaalia.

\section{Vernakulaarin taustoja}

Vernakulaarin käsitteellä on useita osittain samansuuntaisia mutta myös toisistaan poikkeavia merkityksiä. Vernakulaari tarkoittaa kielitieteessä jollain alueella puhuttua kielimuotoa, kuten murretta tai maantieteellisesti rajatun alueen, kuten maan, maakunnan tai kaupungin, asukkaiden puhumaa kieltä. Sen synonyyminä on käytetty myös nimitystä kansankieli. Termin lähtökohtana on latinan kotona syntynyttä (orjaa) tarkoittava sana verna, joka yleisemmin viittasi myös kotoiseen tai kotimaiseen, oman maan tapoihin ja kieleen. Suomessa Henrik Gabriel Porthan kuvasi vernaculus-sanalla yhtäältä runolaulussa käytettyä savon murretta ja toisaalta rahvaan uskonnonopetuksessa käytettyä läntistä murretta. Suomessa nimitys kansankieli oli yleinen 1870-luvulta aina 1970-luvulle asti. Sen avulla erotettiin paikallismurteet yleis- ja kirjakielestä. Tämän lisäksi kansankieli viittasi monikielisessä sääty-yhteiskunnassa kouluttamattomien kansanihmisten puhumiin äidinkieliin, kuten suomeen tai saameen, erotuksena hallinnon ja yläluokan kieleen. Viime aikoina sitä on korvattu vernakulaari-termillä, jonka käsitteellinen kytkös sosiaaliluokkiin ei ole yhtä selkeä. (Tieteen termipankki 13.2.2020: Kielitiede: kansankieli.)

Sittemmin termin vernakulaari merkitys on laajentunut kattamaan moninaisia kulttuurin ilmiöitä, ja sitä on alettu käyttää myös kielitieteen ulkopuolella. Esimerkiksi antropologiassa ja kansanomaisten rakennuskulttuurien nimeämisessä ja tutkimuksessa vernakulaarin 
käyttö yleistyi 1960-luvulla. Englannin kielessä termi vernacular viittaakin nykyään kansankielen ja kansankielisyyden lisäksi myös kansanomaiseen eli tietylle ryhmälle tai maantieteelliselle alueelle tyypilliseen epämuodolliseeen, standardoimattomaan ja usein myös kollektiiviseen kieleen ja kulttuuriin. Erityisesti sitä on käytetty afroamerikkalaisen kulttuurin ja sen perinteestä kumpuavien musiikkityylien yhteydessä. (Bastman, Kallio ja Lehtonen, tässä numerossa.)

Vernakulaarin ja kansankielen käsitteet kytkeytyvät perustavanlaatuisesti suullisen ja kirjallisen kulttuurin välisiin suhteisiin. Folkloristiikassa ja perinteentutkimuksessa kiinnostus suullisen ja kirjallisen suhteeseen juontaa oppialan tutkimushistoriaan ja sen varhaisiin vaiheisiin. Kalevalan ilmestymistä vuonna 1835 seurannut laajamittaisempi kansanrunojen keruu kohdistui pitkään Kalevalan sisältämien runotoisintojen tallentamiseen. Suomalaisen ja vertailevan kansanrunoudentutkimuksen oppiaine muotoutui 1800-1900-luvun vaihteessa Helsingin yliopistossa'. Vielä tässä vaiheessa oppiala kietoutui tiiviisti suullis-kirjallisen teoksen, Kalevalan, ympärille. Siitä huolimatta, että 1800-1900-lukujen vaihteessa suuntauduttiin myös suulliseen lähdeaineistoon tai sen kirjallisiin muistiinpanoihin, Kalevala määritti tieteellistä keskustelua suomalaisen kansanrunoudentutkimuksen piirissä pitkään.

Suullisesti välitetty, mutta dokumentoitu ja kirjoitettu folkloreaines sekä sen suhde perinteen käyttäjien, kerääjien ja "jälkikäyttäjien" kulttuureihin on ollut keskeinen tutkimuskohde folkloristiikassa. Se, mistä puhutaan esimerkiksi suullisena lauluna tai tarinana, on usein jo lähtökohtaisesti tekstualisoitu kirjoitettuun muotoon ja yleensä myös painettu (Seitel 2012; Clifford ja Marcus 1986). Tavallisesti ymmärrys suullisesta kulttuurista ja sen lainalaisuuksista perustuukin kirjallisen kulttuurin tallenteisiin. Siten suullisen ja kirjallisen suhde on folkloristiikan lähdekriittinen ongelma sekä käsitteellinen haaste.

Ennen Kalevalaa suullinen (kansan)perinne miellettiin osaksi kaunokirjallisuuden kenttää (Apo 2006). Kirjallisuus käsitteenä määritteli ja ohjasi folkloren hahmottamista pitkälle 1960-luvulle asti, jolloin siirryttiin vähitellen folkloren yksinomaan tekstikeskeisestä tulkinnasta kohti folkloren käyttäjää ja esitystilannetta (ks. (Hämäläinen, Mikkola, Pikkanen ja Stark, tässä numerossa). Edelleen tekstuaalisuuden ajatus on folkloristiikan keskiössä, mutta sillä ei viitata ainoastaan kirjoitettuihin tallenteisiin tai suullisen ilmaisun siirtymiseen kirjoitettuun muotoon. Tekstuaalisuus tarkoittaa yleisemmin muodollisesti sidottujen ja temaattisesti koherenttien diskurssin osien (suullisten tai kirjallisten) kiertoa kulttuurissa. (Ks. esim. Bauman 2008.) Nykyään on selvää, ettei folklore ole vain suullisesti välittynyttä, vaan se on olemassa kaikenlaisten medioiden myötävaikutuksesta.

Suomalaisessa folkloristiikassa vernakulaarin käsite on yleistynyt laajemmin vasta 2000-luvulla, vaikka käsite esiintyi kulttuurintutkimuksessa jo 1960-luvulla (Lantis 1960). Erityisesti amerikkalaisessa folkloristiikassa on puhuttu "vernakulaarista käänteestä" (Goldstein 2015), ja vernakulaarin käsite on korvannut sellaiset englanninkieliset ilmaisut kuin common, ordinary ja popular (Howard 2005; 2008a; Bauman 2008; Goldstein 2015). Internetin laajenevat kanavat ja mahdollisuudet ovat ajaneet tutkijat analysoimaan uudenlaista, omaehtoista ja hybridistä vernakulaaria toimintaa, jossa amatööriyden ja ammattilaisuuden rajat hälvenevät (Howard 2008a; 2008b). Kansa- ja folk-johdannaisia on purettu folkloristiikassa dentutkimuksen ylimääräiseksi professoriksi hänet nimitettiin 1898, ja oppituoli sai täyden professuurin vuonna 1908. 
runsaasti (esim. Anttonen 2005), minkä lisäksi ne ovat nousseet uudella tavalla esiin niin kutsutussa kansankirjoittajien tutkimuksessa (ks. esim. Laitinen ja Mikkola 2013; Hämäläinen, Mikkola, Pikkanen ja Stark, tässä numerossa; kansa-sanan nykykäytöstä ks. myös Johansson et al. 2018). Folkloristiikan tieteenalan määrittelyssä muun muassa käsite omaehtoinen yhtenä vernakulaarin suomennoksena on alkanut kuitenkin korvata kansa-alkuisia määreitä (esim. Tieteen termipankki: folkloristiikka; Helsingin yliopiston folkloristiikan nettisivut: https://blogs.helsinki.fi/folkloristiikka/).

\section{Näkökulmia vernakulaariin}

Amerikkalaisessa folkloristiikassa sosiolingvistien, arkkitehtien ja kulttuurintutkijoiden uudelleen löytämää vernakulaaria alettiin käyttää satunnaisesti 1960-luvulla, mutta laajemmin sen käyttö yleistyi vasta 1970-luvulla (Noyes 2012, 117). Sillä alettiin käsitteellistää uudelleen ja korvata ideologisiksi miellettyjä termejä folklore ja folklife, jotka kytkivät ilmaisun, ilmaisijan sekä tämän yhteiskunnallisen ja sosiaalisen aseman tiiviisti yhteen (ks. myös Bastman, Kallio ja Lehtonen, tässä numerossa; Hämäläinen, Mikkola, Pikkanen ja Stark, tässä numerossa). Dorothy Noyes kuitenkin huomauttaa, että vaikka vernakulaarin vastakohdaksi ymmärrettiin edelleen jokin oletettu standardi tai sosiaalinen asema, marxilaiset ja jälkikolonialistiset teoriat muuttivat käsitteen sisältöä. Adjektiiviksi muotoutuneella vernakulaarilla kuvattiin hybridejä, yhdisteleviä, luovia ja kriittisiä käytänteitä, joilla kritisoitiin kulttuurin "korkeaa", hyödynnettiin sitä ja luotiin uutta. Viime vuosikymmenten aikana vernakulaarista onkin muodostunut hybridinen käsite: sen avulla kuvataan monimediaisia sekä moninaisia diskursseja ja lähteitä hyödyntäviä ilmaisun repertuaareja, joita yksilöt ja ryhmät luovat ja uusintavat (Primiano 1995; Noyes 2012, 18-19; tämän numeron artikkelit).

Teemanumeron ensimmäisessä artikkelissa Eeva-Liisa Bastman, Kati Kallio ja Tuomas M. S. Lehtonen tuovat esiin, että vaikka vernakulaari kantaa mukanaan yhteiskunnallisten hierarkioiden merkityksiä, tutkimuksen terminä ja tutkimuskohteen kuvauksena vernakulaari on kääntänyt analyyttistä huomiota ilmaisijasta ja tämän sosiaalisesta asemasta itse ilmaisutapaan ja sen kantamiin sosiaalisiin, yhteiskunnallisiin, esteettisiin ja kommunikatiivisiin merkityksiin (Bastman, Kallio ja Lehtonen, tässä numerossa). Tämän teemanumeron ensimmäisessä ja neljännessä artikkelissa vernakulaaria lähestytäänkin ilmaisurekisterin näkökulmasta. Rekisterinäkökulma painottaa ilmaisutavan tilannekohtaisuutta ja siihen kytkeytyviä sosiaalisia merkityksiä. Toisin sanoen yksilöt käyttävät ja valikoivat rekisterejä, jotka assosioituvat tietynlaisiin tilanteisiin ja toimijoihin sekä niihin kytkeytyviin merkityksiin. (Esim. Agha 2004.)

Vaikka folkloristiikassa vernakulaari-termiä ryhdyttiin 1970-luvulta alkaen vähitellen käyttämään folk- ja kansa -johdannaisiin liittyvien ideologisten ongelmien ja painolastien vuoksi, ei vernakulaari käsitteenä ole ollut ongelmaton eikä se ole täysin syrjäyttänyt kansan käsitettä (ks. Hämäläinen, Mikkola, Pikkasen ja Stark, tässä numerossa). Samaan tapaan kuin folklore tai kansanperinne, vernakulaari ei ole kotoperäinen termi, jolla kulttuurin tuottajat ja käyttäjät kulttuuriaan tai toimintaansa kuvaisivat. Vernakulaari onkin ennen kaikkea tutkijan valitsema analyyttinen käsite tutkimiensa kulttuuristen ilmiöiden ja prosessien käsitteellistämiseen ja kuvaamiseen. Vernakulaarit ilmiöt syntyvät ennen kaikkea niissä prosesseissa, joissa ne nimetään vernakulaareiksi. Vaikka vernakulaari ei folkloren tai kansanperinteen tavoin suoraan sido käyttäjää tai ilmaisumuotoa kuuluvaksi johonkin ryhmään, myös sen käyttöön liittyy samankaltaisia ilmaisun muotojen ja ihmisryhmien yhteensitomiseen sekä 
autenttisuuskäsityksiin kytkeytyviä ongelmia, joita folkloren käsitteen ympäriltä on yritetty hahmottaa ja purkaa (Bendix 1997; Anttonen 2005; ks. myös Mullins 2019). Vernakulaarin, kuten minkä tahansa muunkin analyyttisen käsitteen käyttö, edellyttää tutkijalta kriittisyyttä ja refleksiivisyyttä.

Vernakulaarin käsitteen kohdalla on tärkeää kiinnittää huomiota muun muassa sen kontrastiivisuuteen. Kansankielisyyden merkityksessä vernakulaarilla on viitattu kieleen, joka on paikallinen (vs. kansallinen/kosmopoliittinen), epävirallinen (vs. virallinen), normittamaton (vs. normitettu) sekä alempien sosiaaliluokkien kieli (vs. eliitin kieli). Samaan tapaan folkloristiikan tutkimuskohteen määrittelyssä vernakulaarilla on viitattu kansanomaiseen, omaehtoiseen, arkiseen ja jokapäiväiseen erotuksena institutionaalisesta, virallisesta ja standardoidusta. Toisin sanoen vernakulaari on hahmottunut vastakohtana jollekin, jota se ei ole. Vaikka tutkijoiden käytössä vernakulaareiksi nimettyjä ilmiöitä pyrittäisiinkin käsittelemään niiden omista esteettisistä ja pragmaattisista lähtökohdista käsin, vernakulaarin kaltaisiin määritelmiin sisältyy tämän vastakohtaisuuden vuoksi aina myös samankaltaisia ideologisia ja poliittisia ulottuvuuksia sekä stigman potentiaalia kuin folkloren, kansanperinteen sekä matalan tai primitiivisen kulttuurin termeihin, joita vernakulaarilla on pyritty korvaamaan (Goldstein ja Shuman 2012, 116-117; Mullins 2019). Diane E. Goldstein ja Amy Shuman (2012, 117-118) ovatkin ehdottaneet, että stigmatisoituneen vernakulaarin kategoria voi avata uudenlaisia kysymyksiä ja kriittisiä näkökulmia korkean ja matalan, asiantuntijuuden ja maallikkouden sekä kulttuurisen sekoittumisen jäsennyksiin, jotka ovat olleet folkloristiikan - kenties eniten vernakulaarin positiivisiin aspekteihin (tai vernakulaarin idealisointiin) keskittyvän oppialan - määrittelyn ytimessä.

Vernakulaarin käsite implikoi aina jollain tavalla hierarkkisten kategorioiden olemassaoloa. Kuten Willow G. Mullins on todennut, vernakulaari ja virallinen ovat kolikon kaksi puolta eikä toista voi analysoida kiinnittämättä huomiota myös toiseen sekä siihen, mikä sitoo puolia yhteen (Mullins 2019; myös Howard 2008b, 195). Teemanumeron artikkelien ja vernakulaarin käsitteeseen paneutuvan aiemman tutkimuksen pohjalta esitämmekin, että vernakulaarin eräs keskeinen analyyttinen potentiaali kytkeytyy juuri siihen, että se mahdollistaa kulttuurin ilmiöiden ja kulttuuristen prosessien tarkastelun lähtökohtaisesti relationaalisina. Tutkimuksen käsitteenä vernakulaari suuntaa analyyttisen huomion korkean ja matalan, kansan ja eliitin, omaehtoisen/epävirallisen ja virallisen, paikallisen ja globaalin/kosmopoliittisen, julkisen ja yksityisen kaltaisiin vastakohtaisuuksiin ja ennen kaikkea siihen, kuinka kulttuuria ja ilmaisumuotoja hahmotetaan, arvotetaan ja luodaan refleksiivisesti niiden kautta. Sen sijaan että vernakulaari analyyttisenä käsitteenä rajaisi tutkimuskohdetta yksinomaan tietyn ihmisryhmän kulttuuriin, tiettyyn aikaan, tai tiettyjä tyylipiirteitä sisältäviin ilmaisumuotoihin, se voi mahdollistaa näkökulman kääntämisen niihin metakulttuurisiin prosesseihin, joissa kulttuurin ilmiöt, niille annetut merkitykset ja seuraukset syntyvät ja muovautuvat.

\section{Teemanumeron artikkelit}

\section{Ilo-Laulu Jesuxesta ja vernakulaarin monet tasot}

Kokoelman ensimmäinen artikkeli, Eeva-Liisa Bastmanin, Kati Kallion ja Tuomas M. S. Lehtosen kirjoittama "Vernakulaarin monta tasoa: näkökulmia Matthias Salamniuksen runoon Ilo-Laulu Jesuxesta" lähestyy suomenkielisen runouden ja kirjallistumisen historiaa, runokielten käyttöä ja rekisteriytymisprosesseja sekä riimillisen laulun ja kalevalamitan välistä 
dynamiikkaa vernakulaarin käsitteen kautta. Tapausesimerkkinä artikkeli analysoi Matthias Salamniuksen kalevalamittaa ja suullisen runon poetiikkaa noudattavaa kirjoitettua eeposta Ilo-Laulu Jesuxesta (1690). Tämän lisäksi artikkeli erittelee ja vertailee vernakulaarin käsitteen käyttöä folkloristiikassa ja kirjallisuustieteessä.

Salamniuksen Ilo-Laulu Jesuxesta on kristillinen eepos, joka kuvaa Jeesuksen syntymää ja elämänvaiheita sekä valistaa suomenkielistä rahvasta kristinuskon keskeisistä sisällöistä suomeksi ja rahvaan käyttämällä runomuodolla. (Bastman 2019.) Se oli pidetty ja merkittävä teos sekä rahvaan että eliitin piirissä. Vernakulaarin käsitteen näkökulmasta Ilo-Laulu on kiinnostava, sillä se nivoutuu monisyisesti osaksi sekä kirjallistumisen ja kansanomaistamisen että runokielten suullisen ja kirjallisen käytön prosesseja. Tämän lisäksi se kietoutuu yhteen niin kosmopoliittisen kristillisen ja kirjallisen kuin paikallisen suullisen tradition kanssa. Kirjoittajat toteavat, että Ilo-Laulua voidaankin pitää osana vernakularisaatiota (Pollock 2000; Beecroft 2015), joka tässä tapauksessa tarkoittaa suomenkielistä kirjallistumista sekä kirjallisuuden kehittymistä. Teoksen synnyn taustakontekstina olivat Ruotsin 1600-luvun keskitetty kuningasvalta, puhdasoppinen tunnustuksellinen luterilainen kirkko ja kansankielten käyttö uskonharjoituksen kielinä.

Artikkelissaan kirjoittajat tuovat esiin, että vaikka Salamniuksen Ilo-Laulun kohdalla vernakulaarin käsitteen avulla voidaan kuvata sekä kirjallisuuden kansankielistymistä että kansanomaista suullista kulttuuria ja sen ilmaisutapoja, tarkempi analyysi vaatii kansankielisyyttä, epävirallista ja alisteista täsmällisempiä ja erittelevämpiä käsitteitä. Toisaalta he toteavat, että vernakulaarin käsitteen etuna ilmaisumuotojen analyysissä on se, että se ei yhtä suoraviivaisesti kytke muotoa ja yhteisöä tai sosiaalista ryhmää yhteen kuin esimerkiksi kansanrunon käsite. Vernakulaarin käsite voikin avata uudenlaisia mahdollisuuksia ilmaisutapojen, vaihtojen, muutosten ja hierarkioiden tarkasteluun.

Artikkelissa tuodaan kiinnostavasti esiin se, että Ilo-Laulun suhde vernakulaareja koskeviin keskusteluihin ei ole selkeä. Arvostettuna raamatullisena eepoksena se kytkeytyy korkeakulttuuriin, edustaen kuitenkin samaan aikaan luterilaista kansanopetusta, jossa kristinuskon sisältöjä välitetään suomalaisella runomitalla eli rahvaalle vaivattomasti omaksuttavassa muodossa. Sen lisäksi, että Salamnius tuo suullisen runon ja sen mitan osaksi kirjallisuuden resursseja, perinteisellä runomitalla tehty kirjallinen runo saattoi myös välittyä ja tulla edelleen käytetyksi suullisesti. Kirjoittajat toteavat, että "Ilo-Laulun tapaus punoutuu osaksi monisyistä liikettä suullisen ja kirjallisen, koulutetun ja kansanomaisen välillä. Se on myös osa prosessia, jossa kalevalamitan ja riimillisen runouden rajoja ja sävyjä määritetään ja luodaan." He myös osoittavat, että poeettisten ominaisuuksien tarkastelu avaa yleisemminkin näkökulmia eri ilmaisumuotojen ja niitä käyttävien ryhmien välisiin kulttuurisen vaihdon ja omaksumisen prosesseihin.

\section{Miten kansasta tulee vernakulaari?}

Teemanumeron toinen, Niina Hämäläisen, Kati Mikkolan, Ilona Pikkasen ja Eija Starkin kirjoittama artikkeli "Miten kansasta tulee vernakulaari? Kansanrunoudentutkimuksen, kirjallisuushistorian ja kansankirjoittajien tutkimuksen kansakuva 1820-luvulta 2010-luvulle", koskee kansakuvan muutoksia ja jännitteitä Suomessa lähes kahden vuosisadan aikana. Ilmiötä avataan tarkastelemalla neljää tapausesimerkkiä: 1800-luvun alun varhaisia kansanrunousjulkaisuja, ensimmäisiä suomenkielisiä kirjallisuuden kirjallisuushistorioita, 
kansanrunoudentutkimuksen muuttuvaa kuvaa kansanrunojen ja kansanperinteen tuottajista sekä 2000-luvulla käynnistynyttä 1800-luvun itseoppineiden kansankirjoittajien tutkimusta.

1800-luvun ja 1900-luvun alun romanttis-nationalistisessa kontekstissa aidon kansan määreitä olivat esimerkiksi sielukkuus ja aitous. Toisaalta samaan aikaan tietämättömänä pidetty rahvas haluttiin valistuksen keinoin muuttaa paremmaksi tai siitä vaiettiin esimerkiksi dokumentaatiossa ja tutkimuksessa. Kansallisen eliitin kärkijoukkona toimineet kansanrunouden kerääjät ja -tutkijat sekä kirjallisuushistorioitsijat loivat muinaisesta ja ylevästä kansasta tulkintoja, joiden vaikutukset näkyvät tutkimuksessa edelleen. Käsitteet kansa, kansanomainen ja vernakulaari saivat uusia ulottuvuuksia erityisesti 2000-luvun kansankirjoittajien tutkimuksen myötä, kun tutkimusaineistoiksi valikoituivat itseoppineiden omat kirjoitukset ja kokemukset.

Artikkeli kuvaa folkloristiikan ja kirjallisuudenhistorian näkökulmista, miten sivistyneistön määrittelemä kansa oli "viimeinen lenkki" (Apo 1998) perintöketjussa, jonka pelastusoperaatio oli pitkälti juuri tutkimuksen tehtävä. Dokumentaation ja tutkimuksen kohteena ollut perinne määriteltiin aidoksi sen perusteella, oliko se suullista ja kollektiivista. Rahvaan ei itse ajateltu ymmärtäneen runoutensa arvoa, vaan "maalaisilla on melko varastot vanhoja laulujamme, jotka heillä ovat käyttämättöminä", kuten A. I. Arwidsson ([1821] 1931, 121) asian ilmaisee. Lisäksi perinne oli arvotettua ja runolajit hierarkisoitu. Henrik Gabriel Porthanin tutkimuksessa Suomalaisesta runoudesta (1766-1778) todetaankin, että loppusoinnulliset laulut ovat arvottomia, ja niistä pitävät ne, jotka eivät kykene ymmärtämään loppusoinnuttomia eli kalevalamittaisia runoja (Porthan [1766-1778] 1983, 46).

Toisaalta artikkeli tarkastelee, miten vanhoja, kalevalamittaisia runoja taitaneet laulajat tai itseoppineet kirjoittajat, "talonpoikaisrunoniekat", asetettiin edustamaan ihanteellista kansaa kirjoittamalla heidät osaksi kirjallisuushistorian kaanonia. Kansan omaehtoiset suullis-kirjalliset tuotokset nähtiin toisaalta myös ongelmallisina, sillä ne rikkoivat yhtenäisyyttä ja eliitin ylläpitämää kuvaa kirjoitus- ja lukutaidottomasta kansanosasta ja tämän idealisoidusta perinteestä (kalevalamittainen runous). Kalevalamittainen perinne arvotettiin pitkään rahvaan itsensä suosimaa laulu- ja runoperinnettä arvokkaammaksi. Suositut arkkiveisut olivat puolestaan kirjallisuushistorioissa esimerkkejä haitallisesta kirjallisesta toiminnasta.

1900-luvun alkupuoliskon tutkijoiden tähtäimessä ei siis ollut monimuotoinen kansa, eikä perinteen taitajien taustoista oltu laajassa mielessä kiinnostuneita tai folklorea taitaneiden henkilöiden taustoja sen kummemmin kirjattu ylös. Tekijöiden mukaan modernin yhteiskunnan "kehityksestä saatiin folkloren osalta kiinni 1960-luvulla, jolloin käsitystä homogeenisesta kansasta ryhdyttiin purkamaan niin kirjallisuushistoriassa kuin folkloren tallentamisessa ja analysoimisessa". Näin folkloristiikassa siirryttiin vähitellen pois kansallisesta ja luokkaperusteisesta kansa-käsitteestä kohti mitä tahansa ryhmää, jolla oli yhteistä folklorea. Käsitys kansanomaisesta ja kansasta hahmottui edelleen 2000-luvun kansankirjoittajien tutkimuksen myötä. Itseoppineita kirjoittajia koskevat tutkimukset havainnollistivat, ettei kansa ollutkaan anonyymia ja kollektiivista vaan joukko ihmisiä, joilla oli "nimi, elämänhistoria ja oma ääni, jolla he tulkitsivat itse omaa kulttuuriaan".

Rahvaan vernakulaari kirjallinen tuotanto tarjoaa uuden tavan lukea myös Suomen suuriruhtinaskunnan kirjallisuushistorioita. Artikkeli osoittaa, että Suomen suuriruhtinaskunnassa 
laaditut varhaiset kirjallisuushistoriat yrittivät sulauttaa yhteen alueen ensimmäiset vernakulaarin kirjallisuuden kerrostumat ja 1800-luvulla muotoutumassa olleen kansallisen kirjallisuuden. Tutkimuksen kannalta näiden varhaisten kirjallisuuden kerrostumien louhiminen ja uudelleenarviointi on mitä mielenkiintoisin tehtävä.

Artikkelissa osoitetaan, miten käsite vernakulaari ja sen tarkoittama yhteisöjen omaehtoinen kulttuuri-ilmaisu ilmestyvät vähitellen kansanomaisen rinnalle tai tilalle tieteellisissä diskursseissa. Sisällöllisessä mielessä vernakulaari alkoi hahmottua tutkimuksissa sitä mukaa kun kollektiivinen kansa väistyi ala- ja osakulttuureita sekä yksilöä ja yksilöllisiä tulkintoja korostavien tutkimussuuntausten tieltä. Silti kansa eksplisiittisenä käsitteenä on säilynyt esimerkiksi kansankirjoittajien tutkimuksessa, ja oikeastaan vasta viimeisten vuosikymmenien tutkimus (esim. Bauman 2008; Goldstein 2015) on paneutunut kansa-käsitteen ideologiseen painolastiin ja paikoin korvannut sen vernakulaarilla.

\section{Omaehtoisen muistamisen materiaalisuus ja monimediaisuus}

Teemanumeron kolmas artikkeli, Ulla Savolaisen, Karina Lukinin ja Anne Heimon kirjoittama "Omaehtoisen muistamisen materiaalisuus ja monimediaisuus: muistitietotutkimus ja uusmaterialismi", lähestyy vernakulaaria omaehtoisen muistamisen ja historian tuottamisen näkökulmasta. Artikkeli paikantuu suomalaiseen muistitietotutkimukseen, jonka tulo folkloristiikan ja perinteentutkimuksen kentälle voidaan tulkita osaksi 1960-luvulla alkanutta vernakulaaria käännettä (Goldstein 2015). Sen puitteissa kulttuurien tutkimuksessa voimistui kerronnallisten aineistojen ja henkilökohtaisen tiedon merkitys tutkimuskohteina. Artikkelissa vernakulaari tarkoittaa ennen kaikkea omaehtoisuutta. Omaehtoisella muistamisella ja historiantuottamisella tarkoitetaan artikkelissa "muistelijoiden omasta aloitteesta ja lähtökohdista, itse valitsemansa muodon ja median kautta tapahtuvaa menneisyyden tulkintaa". Tässä taustalla voidaan nähdä myös Jorma Kalelan ajatus siitä, että historian esityksiä eivät ole pelkästään sellaisiksi kirjoitetut tekstit ja historian puhutut tulkinnat vaan vaikkapa arkipäiväiset "kertomukset jostain huomiota herättävästä rakennuksesta tai television uutiskuviin liittyvät selostukset". (Kalela 2010, 40-41; ks. myös esim. Kalela 2006; 2012; Heimo 2014.)

Artikkelin lähtökohtana on se, että vaikka omaehtoinen muistaminen tapahtuu mitä moninaisimpien välineiden eli medioiden kautta ja niiden mahdollistamalla tavalla, muistitietotutkimuksen huomio on keskittynyt vahvasti muistamisen kerronnallisen sekä kielellisen eli suullisen ja kirjallisen muodon kysymyksiin. Artikkeli pyrkii monipuolistamaan muistitietotutkimuksen muistelun keskusteluja pureutumalla muistamisen materiaalisten ja diskursiivisten aspektien vuorovaikutukseen soveltaen niin kutsutun uusmaterialismin teorioita ja pohtimalla niiden antia muistitietotutkimukselle (ks. myös Kuusisto-Arponen ja Savolainen 2016). Muistamisen materiaalisuuden ja monimediaisuuden erittelyn lisäksi artikkelissa pohditaan medioiden yhteistoiminnan analyysin mahdollisuuksia kolmen omaehtoista muistamista edustavan tapausesimerkin analyysin kautta.

Artikkelin ensimmäinen tapausesimerkki analysoi vuoden 1918 sisällissodan muistamista Facebookissa. Se erittelee vuoden 1918 muistamisen piirteitä sekä esittelee muistamisen monimediaisuutta eli kielellisen, visuaalisen ja materiaalisen yhteenkietoutumista ja Facebookin toimijuutta inhimillisen toimijuuden rinnalla. Esimerkki tuo esiin sen, että samalla kun Facebook on mahdollistanut uudella tavalla medioiden, kuten tekstin ja kuvan vuorovaikutuksen, se on muuttanut käsitystä julkisen ja yksityisen muistamisen suhteista. Toisessa 
tapausesimerkissä tarkastellaan inkerinsuomalaistaustaisen kirjailijan Ella Ojalan kirjallisuutta analysoimalla erityisesti valokuvan ja kerronnan tarjoumia ja keskinäistä vuorovaikutusta materiaalisina ja esittävinä muistamisen medioina. Tämän vuorovaikutuksen kautta Ojalan muistaminen kytkeytyy yksityisen ja julkisen sekä yksilöllisen ja kollektiivisen välisen suhteen pohtimiseen ja rakentamiseen. Artikkelin kolmannessa tapausesimerkissä tarkastellaan nenetsien poroturkisvaatteisiin eli paanitsoihin ja niiden materiaalisuuteen kytkeytyvää ajallisiin suhteisiin ja omaehtoiseen historiantuottamiseen kytkeytyvää merkityksenantoa. Se purkaa alkuperäiskansojen aineellisen kulttuurin ja menneisyyksien tutkimukseen kytkeytyviä valta-asetelmia ja pohtii, miten vaatteita on ollut mahdollista tulkita ja esittää.

Artikkelissaan kirjoittajat ehdottavat Dorothy Noyesin $(2012,18-19)$ vernakulaarin toiminnan hybridiä luonnetta koskevan ajatuksen pohjalta, että medioiden vuorovaikutuksen analysoinnin avulla on mahdollista ymmärtää ja kuvata omaehtoista muistelua ja historian tuottamista sekä purkaa korkean ja matalan, julkisen ja yksityisen sekä objektiivisen ja subjektiivisen kaltaisia vastakkainasetteluja. Kirjoittajat huomauttavat, että on tärkeää ymmärtää vernakulaarin toiminnan jatkuva vuorovaikutus myös niin kutsutun virallisen tai hallitsevan kanssa. Kirjoittajat esittävät myös, että suuntaamalla huomio siihen, että muistelijat ja heidän kertomuksensa kuuluvat laajempaan toimijoiden ja materiaalisuuksien verkostoon, uusmaterialismin näkökulma aiheuttaa muutoksen tiedon tuottamisen lähtökohtiin. He toteavat materian toimijuuden huomioimisen antavan aiheen kysyä, "mitä tarkalleen tarkoitamme, kun puhumme omaehtoisuudesta? Minkälaisilla ehdoilla muistaminen lopulta tapahtuu?"

\section{Vernakulaari vertaisuutta ilmaisevana rekisterinä}

Teemanumeron neljäs artikkeli on Kaarina Kosken ja Riikka Turtiaisen kirjoittama "Vernakulaari verkossa: vertaisuuden ilmaisemisen digitaaliset ulottuvuudet". Artikkeli tarkastelee vernakulaaria kulttuuria sekä rekistereitä digitaalisissa ympäristöissä. Vernakulaarin tarkastelu rekisterinä korostaa sosiaalisen asemoitumisen tilannekohtaisuutta. Artikkelin teoreettisina lähtökohtina ovat Robert Glenn Howardin hahmotukset vernakulaarin hybridisyydestä (Howard 2008a; 2008b) sekä vernakulaarista auktoriteetista (Howard 2013; 2019), ja siinä keskitytään analysoimaan erityisesti vernakulaarin rekisterin hyödyntämistä ammattimaisissa yhteyksissä. Artikkelissa vernakulaarin hybridisyydellä tarkoitetaan institutionaalisen tai kaupallisen ja omaehtoisen kietoutumista toisiinsa sosiaalisessa mediassa. Vernakulaari auktoriteetti taas tarkoittaa joko vernakulaariksi mielletyn diskurssin tai yksilön sosiaalista arvo- ja vaikutusvaltaa, ja sen syntyminen edellyttää verkostojen olemassaoloa. Uudet viestintäteknologiat ovatkin mahdollistaneet kiinnostuneiden tai samanmielisten ihmisten verkostoitumisen tietyn teeman ympärille riippumatta institutionaalisista toimijoista ja näin ollen luoneet tilaisuuksia vernakulaarien auktoriteettien muodostumiselle.

Vernakulaarin hybridisyyttä sekä vernakulaaria auktoriteettia analysoidaan artikkelissa kolmen tapaustutkimuksen kautta, ja niiden analyysissä hyödynnetään folkloristiikan, digitaalisen kulttuurin ja mediatutkimuksen sekä retoriikan näkökulmia. Ensimmäinen tapausesimerkeistä käsittelee epäonnistuneita kakkuja koskevaa viihdettä. Siinä hybridisyys ilmenee ammattimaisen ja omaehtoisen kulttuurituotannon välisinä vuorovaikutussuhteina ja lainaamisina. Toisessa tapausesimerkissä tarkastellaan hybridiseen toimijuuteen perustuvaa vernakulaaria auktoriteettia analysoimalla Perussuomalaisten kahden puheenjohtajan, Timo Soinin ja Jussi Halla-Ahon, erilaisia tapoja tuottaa vernakulaaria auktoriteettia. Kolmas 
tapausesimerkki analysoi somevaikuttajia, joiden toiminta sijoittuu ammattimaisen ja kaupallisen sekä omaehtoisen välimaastoon. Kirjoittajat analysoivat, kuinka somevaikuttajat kykenevät samaan aikaan sekä säilyttämään vernakulaarin auktoriteettinsa että toimimaan ammattimaisesti esimerkiksi kaupallisten yhteistöiden kautta.

Vernakulaarin hybridisyyttä digitaalisissa ympäristöissä luonnehtii institutionaalisen ja kaupallisen sekoittuminen monilla tavoin yhteen omaehtoisen kanssa. Kyse ei ole yksinomaan siitä, että sosiaalisen median käyttäjät soveltaisivat kaupallisia tai kansainvälisiä tyylejä ja ilmaisutapoja osaksi omaa elämäänsä ja luovaa ilmaisuaan. Yhtä lailla ammattimaiset toimijat, kuten kaupalliset tahot, poliitikot ja instituutiot, pyrkivät omaksumaan vernakulaareja ilmaisuja vedotakseen niin kutsuttuun suureen yleisöön. Kyse on vernakulaarin rekisterin hyödyntämisestä vertaisuuden ilmaisuun. Koski ja Turtiainen kuitenkin huomauttavat, että vaikka sosiaalinen media tekee kaupallisen ja vernakulaarin yhteenkietoutumisen uudella tavalla näkyväksi, kyse ei ole uudesta tai vain digitaalisia ympäristöjä koskevasta ilmiöstä. Eri sosiaali- tai yhteiskuntaluokkien, kulttuurien, institutionaalisen ja omaehtoisen sekä kosmopoliittisen ja paikallisen välillä on ollut aina vuorovaikutusta molempiin suuntiin (ks. myös Bastman, Kallio ja Lehtonen, tässä numerossa). Kosken ja Turtiaisen artikkelin keskeinen ja tärkeä kontribuutio vernakulaaria digitaalisissa ympäristöissä koskevaan keskusteluun on se, että siinä kehitetään vernakulaarin käsitettä eteenpäin tarkastelemalla sitä vertaisuuden ilmaisun mahdollistavana rekisterinä. Se on uudenlainen näkökulma digitaalisten ympäristöjen ja laajemminkin nykykulttuurin hybridien toimijuuksien ja toimintojen analysointiin.

\section{Kirjallisuus}

Agha, Asif. 2004. "Registers of Language." Teoksessa A Companion to Linguistic Anthropology, toimittanut Alessandro Duranti, 23-45. Malden: Blackwell. https://doi. org/10.1002/9780470996522.ch2

Anttonen, Pertti. 2005. Tradition Through Modernity: Postmodernism and the Nation-State in Folklore Scholarship. Helsinki: Finnish Literature Society. https://doi.org/10.21435/ sff.15

Apo, Satu. 1998. "Suomalaisuuden stigmatisoinnin traditio." Teoksessa Elävänä Euroopassa: Muuttuva suomalainen identiteetti, toimittaneet Pertti Alasuutari ja Petri Ruuska, 83-128. Tampere: Vastapaino.

Apo, Satu. 2006. "Kansanlaulujen ääni 1700-luvun kirjallisuudessa: Johdatus Macphersonin, Percyn ja Herderin runojulkaisuihin." Teoksessa Herder, Suomi, Eurooppa, toimittaneet Sakari Ollitervo ja Kari Immonen, 216-264. Helsinki: Suomalaisen Kirjallisuuden Seura.

Arwidsson, Adolf livar. 1931 [1821]. "Kansallisuudesta ja kansallishengestä [Om Nationalitét och National Anda, Åbo Morgonblad]." Teoksessa Suomen kansalliskirjallisuus VII, toimittaneet Emil Nestor Setälä, Viljo Tarkiainen ja Vihtori Laurila, 103-124. Helsinki: Otava.

Bauman, Richard. 2008. "The Philology of the Vernacular." Journal of Folklore Research 45(1): 29-36. https://doi.org/10.2979/JFR.2008.45.1.29

Beecroft, Alexander. 2015. An Ecology of World Literature From Antiquity to the Present Day. London \& New York: Verso. 
Bendix, Regina. 1997. In Search of Authenticity: The Formation of Folklore Studies. Madison: University of Wisconsin Press.

Clifford, James ja George E. Marcus. 1986. Writing Culture: The Poetics and Politics of Ethnography. Berkeley, Los Angeles, London: University of California Press.

Goldstein, Diane E. 2015. "Vernacular Turns: Narrative, Local Knowledge, and Changed Context of Folklore." Journal of American Folklore 128(508): 125-145. https://doi. org/10.5406/jamerfolk.128.508.0125

Goldstein, Diane E. ja Amy Shuman. 2012. "The Stigmatized Vernacular: Where Reflexivity Meets Untellability."JournalofFolkloreResearch 49(2):113-126.https://doi.org/10.2979/ jolkrese.49.2.113

Heimo, Anne. 2014. “Esitelmä: Omaehtoista historiantuottamista." Elore 21(2). https://doi. org/10.30666/elore.79158

Howard, Robert Glenn. 2005. "A Theory of Vernacular Rhetoric: The Case of the 'Sinner's Prayer' Online." Folklore 116(2): 172-188. https://doi.org/10.1080/00155870500140214

Howard, Robert Glenn. 2008a. "The Vernacular Web of Participatory Media." Critical Studies in Media Communication 25(5): 490-513. https://doi.org/10.1080/15295030802468065

Howard, Robert Glenn. 2008b. "Electronic Hybridity: The Persistent Processes of the Vernacular Web." Journal of American Folklore 121(480): 192-218. https://doi. org/10.1353/jaf.0.0012

Howard, Robert Glenn. 2013. "Vernacular Authority: Critically Engaging 'Tradition"' Teoksessa Tradition in the Twenty-First Century: Locating the Role of the Past in the Present, toimittaneet Trevor Blank ja Robert Glenn Howard, 72-99. Logan: Utah State University Press. https://doi.org/10.7330/9780874218992.c03

Howard, Robert Glenn. 2019. "Vernacular Authority Speaks for the Glock: Heterogeneous Volition in an Institutional Proverb."Teoksessa Folkloristics in the Digital Age, toimittaneet Pekka Hakamies ja Anne Heimo, 73-91. Helsinki: Academia Scientiarum Fennica.

Johansson, Marjut, Jarmo H. Jantunen, Anne Heimo, Mirka Ahonen ja Veronika Laippala. 2018. "Verkkokeskustelujen kansa: korpusavusteinen diskurssianalyysi Suomi24keskustelupalstasta." Sananjalka 60: 96-117. https://doi.org/10.30673/sja.69963

Kalela, Jorma. 2006. "Muistitiedon näkökulma historiaan." Teoksessa Muistitietotutkimus: metodologisia kysymyksiä, toimittaneet Outi Fingerroos, Riina Haanpää, Anne Heimo ja Ulla-Maija Peltonen, 67-92. Helsinki: Suomalaisen Kirjallisuuden Seura.

Kalela, Jorma. 2010. "Historian rakentamisen mieli ja tutkijan valinnat."Teoksessa Medeiasta pronssisoturiin: kuka tekee menneestä historiaa?, toimittaneet Pertti Grönholm ja Anna Sivula, 40-59. Turku: Turun historiallinen yhdistys ry.

Kalela, Jorma. 2012. Making History: History and Uses of the Past. London: Palgrave Macmillan. https://doi.org/10.1007/978-0-230-35658-0

Kuusisto-Arponen, Anna-Kaisa ja Ulla Savolainen. 2016. "The Interplay of Memory and Matter: Narratives of Former Finnish Karelian Child Evacuees." Oral History Journal 44(2): 59-68.

Laitinen, Lea ja Kati Mikkola (toim.). 2013. Kynällä kyntäjät. Kansan kirjallistuminen 1800luvun Suomessa. Helsinki: Suomalaisen Kirjallisuuden Seura.

Lantis, Margaret. 1960. "Vernacular Culture." American Anthropologist 62(2): 202-216. https://doi.org/10.1525/aa.1960.62.2.02a00020 
Mullins, Willow G. 2019. "Our Lady of Authenticity: Folklore's Articles of Faith." Teoksessa Implied Nowhere: Absence in Folklore Studies, toimittaneet Shelley Ingram, Willow G. Mullins ja Todd Richardson, 19-37. Jackson: University Press of Mississippi. https://doi. org/10.14325/mississippi/9781496822956.003.0002

Noyes, Dorothy. 2012. "The social base of folklore." Teoksessa A Companion to Folklore., toimittaneet Regina Bendix \& Galit Hasan-Rokem, 13-30. Malden, Mass.: WileyBlackwell. https://doi.org/10.1002/9781118379936.ch1

Porthan, Henrik Gabriel. 1983 [1766-1778]. Suomalaisesta runoudesta. Kääntänyt ja johdannon kirjoittanut liro Kajanto. Helsinki: Suomalaisen Kirjallisuuden Seura.

Primiano, Leonard Norman. 1995. "Vernacular Religion and the Search for Method in Religious Folklife." Western Folklore 54: 37-56. https://doi.org/10.2307/1499910

Salamnius, Matthias. 1690. Ilo-Laulu Jesuxesta. Turku: Johan Winter.

Seitel, Paul. 2012. "Three Aspects of Textuality." Teoksessa A Companion to Folklore, toimittaneet Regina F. Bendix ja Galit Hasan-Rokem, 75-93. Malden, Mass.: WileyBlackwell. https://doi.org/10.1002/9781118379936.ch4

Tieteen termipankki 13.2.2020: Kielitiede:kansankieli. Tarkka osoite: https:// tieteentermipankki.fi/wiki/Kielitiede:kansankieli

Tieteen termipankki 26.3.2020: Folkloristiikka. Tarkka osoite: https://tieteentermipankki.fi/ wiki/Luokka:Folkloristiikka

Outi Fingerroos on etnologian professori Jyväskylän yliopistossa. Hänen tutkimuksensa keskittyy muistitietotutkimukseen, etnisyyteen ja identiteetteihin, siirtolaisuuteen, poikkeusaikojen muistamiseen ja yhteiskuntaetnologiaan.

Niina Hämäläinen on folkloristi ja hän työskentelee Kalevalaseuran toiminnanjohtajana. Parhaillaan hänellä on työn alla Kalevalan kriittinen editio, Avoin Kalevala, sekä Suomen Akatemian projektissa (nro 322071) väheksyttyjen aineistojen tutkiminen.

Ulla Savolainen (https://researchportal.helsinki.fi/en/persons/ulla-savolainen) on folkloristiikan dosentti. Hän työskentelee Suomen Akatemian tutkijatohtorina (SA 1308661) Helsingin yliopistossa. Hän tutkii inkeriläisten kokemuksiin kytkeytyvää kirjallisuutta sekä johtaa inkeriläisten ylirajaisia muistikulttuureja tarkastelevaa tutkimushanketta. 